\title{
Sukuk Default Regulation in Malaysia and United Arab Emirates: Comparative Analysis
}

\author{
Saheed Abdullahi Busari(1), Luqman Zakariyah ${ }^{(2)}$, Akhtarzaite Binti Abdul Aziz(3)
}

\begin{abstract}
The nascent Islamic finance industry is still facing the challenges of uncertainties in legal regimes, Shari'ah interpretations, the right of investors, and remedies in default circumstances. The event of Sukūk default is one of the significant challenges faced by the Islamic capital market. The recent Dana Gas Sukūk default triggered by Sharì'ah compliance interpretations has shown the extent of danger that moral hazards could cause to the entire Islamic finance space. Scholars have argued that the Shari'ah-compliant arguments witnessed in the industry were because of the nature of the capital market framework of any particular jurisdiction and were not significantly Shar'’'ah issues. This study aims to carry out a brief comparative analysis of the default cases in Malaysia and the United Arab Emirates (UAE). The study compares the legal jurisdiction and regulatory framework in summary-background of the judges and court decision samples based on these structures and how they have influenced Sukuk default regulations in the jurisdiction. This study employs a comparative analysis by considering fundamental elements in the regulatory framework.

Keywords: Sukuk Default, Regulatory Framework, Legal Jurisdictions.

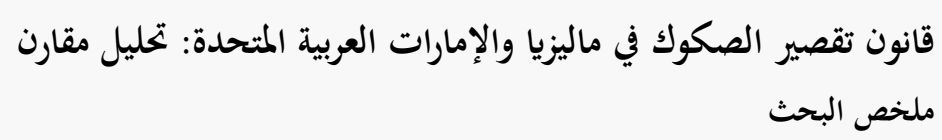

الصناعة المالية الإسلامية الوليدة لا تزال تواجه تحديات من أوجه عدم التيقن في النظم القانونية، تفسير الشريعة، حقوق المستثمرين والانتصاف في حالة عدم الوفاء. وقوع تقصير الصكوك هو من أهم التحديات التي تواجه سوق المال الإسلامي. وتقصير الصكوك الأخيرة لدانا غاز نتيجة من تفسير

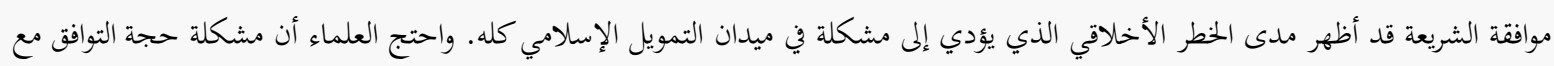
الشريعة الإسلامية التي شهدت في الصناعة المالية الإسلامية كانت بسبب طبيعة إطار سوق رأس المال لولاية قضائية معينة وليست مسألة شرعية محضة. وتهدف هذه الدراسة تحليل مقارنة موجزة بين قضايا عدم الوفاء في ماليزيا والإمارات العربية المتحدة، وتقارن بين الولاية القانونية والإطار

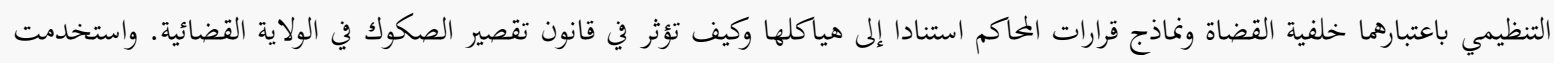
الدراسة أسلوب التحليل المقارن مراعيا العناصر الأساسية في الإطار التنظيمي. كلمات مفتاحية: تقصير الصكوك، الإطار التنظيمي، النظم القانونية.

(1) PhD Student, Dept. of Fiqh and Usul al-Fiqh, International Islamic University Malaysia. mrbusarisaheed@gmail.com

(2) Assoc. Prof., Dept. of Fiqh and Usul al-Fiqh, International Islamic University Malaysia.luqzak@iium.edu.my

(3) Assist. Prof., Dept. of Fiqh and Usul al-Fiqh, International Islamic University Malaysia. akhtarzaite@iium.edu.my
\end{abstract}

\section{Contents}

1. Introduction

2. Background of Sukuk Investment in Malaysia and United Arab Emirates

3. Regulatory Framework in Malaysia \& the UAE

3.1 The Islamic Capital Market Regulations from the Security Commission Malaysia

3.2 Laws on Default Issues

4. External Regulatory Elements

4.1 The United Nations Commission on International Trade Law (UNCITRAL)

4.2 The Islamic Financial Service Board (IFSB)

5. Juristic Analysis of Two Court Judgements

6. Conclusion and Recommendations

References

Endnotes

\section{Introduction}

The philosophy of Sukuk is risk sharing rather than risk transfer practices in conventional bonds (Al-Hilmī S. A., 2014). However, applications of Sukuk investment have contributed immensely to the development of infrastructure, particularly among Muslim nations. The Sukuk has widened the investment inclusion of a more substantial percentage of investors, particularly among Muslims who are conscious of the Shari'ah compliance and challenges that the conventional bonds pose to potential investors. For instance, as of 2008, both Malaysia and the United Arab Emirates (UAE) accounted for over $70 \%$ of the total Sukuk market. The central banks of these countries can use Sukuk instruments to provide liquidity tools for banks, 
institutions, agencies and corporations (Kuwait Finance House, 2010). Despite these contributions, numerous compliant issues are challenging the growth of the nascent industry. For instance, the moral hazard triggered by incessant Sharī’ah argument arising among contractual parties is working against the growth of the sector.

A breach of contractual terms usually triggers Sukuk default. Cash flow issues chiefly cause the violation of the contractual agreement. Hence, the subsequent reaction of contractual parties in the event of a default depends mainly on the terms in the prospectus and the contractual agreement (Emily $\mathrm{M}$. W., 2012). The contractual clauses guide the contractual agreement itself. These contractual clauses can be enforced, and the binding-ness of these clauses depends on the entire framework, which includes the governing laws, the role of regulatory bodies, the rating agencies, the Sharī'ah panel, certainty of the legal regime and the dispute resolution mechanism (Robert S. A., 1993).

This study aims to explore the juristic analysis of Sukuk default cases in the two jurisdictions. The research also shows the differences between the Malaysian and UAE experiences when dealing with Sukuk default. Firstly, Malaysia is a leading jurisdiction for Islamic finance in the world, with a robust and successful Sukuk market. The success could be due to the presence of a robust framework which includes a legal framework for the Islamic capital market, the enactment of the Islamic Financial Service Act (IFSA) and a centralized Sharī'ah Advisory Council (Rodney G. C. \& Zulkifli Aziz M. Z., 2017). Meanwhile, the United Arab Emirate jurisdiction is examined in this study, because of the recent Dana Gas Sukuk default that has stunned the entire Islamic finance market, particularly the contradicting court decision between the Sharjah judiciary and the English court.

Therefore, this study demonstrates a comparative analysis of the framework of Malaysia and of the UAE, and the fundamental elements of this framework that have influenced Sukuk default cases in the two jurisdictions. The remaining part of this study is as follows: (a) a background of Sukuk investment in Malaysia and the UAE, (b) the regulatory framework in
Malaysia and the UAE, (c) the external regulatory elements, (d) a juristic analysis of Sukuk default court cases in Malaysia and the UAE, and (e) conclusion and recommendations.

\section{Background of Sukuk Investment in Malaysia and United Arab Emirates}

The researchers have carefully selected three different jurisdictions in Sukuk default because of their peculiarity in the subject matter. For example, Malaysia is assumed to be a leading jurisdiction of Islamic finance from the south-east Asia region, with over $70 \%$ of the global Sukuk market. The contribution of Malaysia to the development of Islamic banking and the Islamic capital market, especially, cannot be overemphasized (IDB, IRTI \& IFSB, 2015). Although Malaysian law adopted its constitution from English law after the charter of 1807 which granted the use of the law of England, after the occurrence of chaos due to differences in the applicable laws for the Malays, Chinese and Indians. While the Muslim Malays adopted the Islamic law, the Chinese and Indian were using their customary law. After Merdeka (independence), the Malaysian legal system has primarily relied on the legislation and case law (Ahmad Ibrahim \& Ahilemah Joned, 1995). However, before the emergence of Islamic finance in Malaysia, the application of Islamic law did exist, but it was restricted to the state level while the federal constitution has been declared supreme (Federal Constitution, 2010). Moreover, the Islamic finance industry in Malaysia with its comprehensive and robust regulations falls under the purview of the federal law. The Malaysian capital market framework is assumed to be marketbased. ${ }^{(1)}$ Regulation and supervision are said to be market-based if their protection and consideration cover all market stakeholders such as creditors, debtors, regulators, and the industry at large (Zamani Abdul Ghani, 2007). However, experts have opined that the success story of the growth and volume of Sukuk investment in Malaysia is because of its robust regulation and regulatory bodies. Hence, all the market players are comfortable and evenly protected by the law (David G. Epstein, 2010). The Malaysian Islamic capital market framework encapsulates two primary mechanisms, which are, first, the dispute resolution 
mechanism, and second, the Sharī'ah governance. The dispute resolution mechanism provides two remedial mechanisms, the federal court based on the English court, and the arbitration panel mediation. According to Rusni Hassan, (2018), Sharī'ah Governance is responsible for the Sharī'ah risk and Sharī'ah audit. The framework states that the Sharī'ah Advisory Committee (SAC) is a centralized Sharī'ah body, while the Sharī'ah committee of each financial institution operates under the purview of the SAC, and report Sharī'ah issues to the SAC for further ratification. ${ }^{(2)}$ Moreover, the Malaysian Islamic capital market framework is considered robust because of comprehensive features such as the relation between Bank Negara, the securities commission, Labuan FSA, the centralized Sharī'ah advisory board and the local Sharī'ah committee of various financial institutions. ${ }^{(3)}$ (Laws of Malaysia Act 372, 1989). The Malaysian legal framework is considered comprehensive because of the integrative approach of including Sharī'ah law in the entire Islamic finance regulation. The Islamic banking act of 1983, the Takaful act of 1984, and the banking and financial institution act (BAFIA) of 1989 authorized the conversion of conventional financial institutions into Islamic banks (Laws of Malaysia Act 372, 1989). In 2005, Bank Negara developed the Sharī'ah governance framework to regulate the role of the Sharī'ah committee of various financial institutions and their relationship with the Sharī'ah advisory council and Bank Negara Malaysia (Akram Laldin M. \& Hafas Furqani, 2013). Nevertheless, the legal documentation on Islamic financial transactions and contractual agreements are considered in the Malaysian legal system as principles of the Law of Contracts, and any dispute and disagreement that may arise among contractual parties in Islamic financial transactions fall under the jurisdiction of the civil courts (Rafisah Mat Radzi \& Nurul Aini Muhamed, 2012).

Malaysia seems to be a model jurisdiction that has a comprehensive and regulatory framework for the Islamic finance industry and practice. For instance, in Sukuk investments, the Securities Commission Malaysia has developed a robust legal and Sharī'ah framework based on the International Organization of Securities Commissions (IOSCO), Asia regulations for the Islamic capital market, especially Sukuk investments. (Suruhanjaya Sekuriti Malaysia, 2016). The Islamic capital market in Malaysia is managed and regulated by the Securities Commission Malaysia. After the expansion of the Malaysian market, the commission decided to open a separate department for the Islamic capital market under the Securities Commission. The department is responsible for regulating all Islamic capital market transactions in Malaysia with robust supervision to ensure the activities, operations and contractual agreements are in line with the legal and Sharī'ah framework (ISRA, 2012).

On the other hand, the UAE experience is currently one of the major issues in the Islamic finance industry. The Dana Gas Sukuk default cases between the jurisdiction of the UAE and the United Kingdom is a challenge to the entire Islamic finance market. The debtor (Dana Gas PJSC) is favored by the Sharjah court based on the UAE law that is embedded in Islamic interpretation of Islamic law while the creditors (Dana Gas Șukūk Ltd) are supported by the English law that declares the purchasing undertaking of the contractual agreement valid (Dana Gas PJSC (Claimant) V. Dana Gas Șukūk Ltd and Ors., 2017).

\section{Regulatory Framework in Malaysia \& The UAE}

Firstly, Malaysia's regulation and supervision of the Sukuk Investment seems to be robust and comprehensive. The study conducted by Mohd Faizal Kamarudin et al. (2014) on the profile of defaulters in the Malaysian Sukuk market shows that the occurrence of default cases, particularly in Sukuk investment, may affect the growth of the global Islamic finance market. (Mohd Faizal Kamarudin et al., 2014). Although the Islamic finance industry has witnessed a significant advancement in the last decade, the Gulf Cooperation Council (GCC) market is most likely to be affected because of the challenges of legal jurisdiction and the issues of Sharī'ah compliancy that rock the market (IFSB, 2017). However, Malaysia remains a leading market of Islamic finance with tight regulations and supervision by its regulatory agencies to ensure prudential standards in the market. (Rodney G. C. \& Zulkifli Aziz M. Z., 2017). Some legal experts and researchers have asserted that one of the critical factors 
responsible for the success of the Islamic finance industry in Malaysia is the provision of comprehensive regulation and supervision (Rodney G. C. \& Zulkifli Aziz M. Z., 2017). Furthermore, the Malaysian legal framework for the Islamic finance industry is market oriented. That is, regulation and prudential standards evenly protect all stakeholders in the sector (Apnizan Abdullah, 2017).

\subsection{The Islamic Capital Market Regulations from the Security Commission Malaysia:}

The Security Commission of Malaysia was established on 1 March 1993 under the Securities Commission Act 1993. From its inception, the commission has operated as a self-funding statutory body which generates its income from levies and application fees. The Security Commission of Malaysia provides a regulatory framework for the capital market investment and has the power to investigative and enforce regulation within its jurisdiction by reporting directly to the Minister of Finance who tables its accounts in Parliament annually (Securities Commission Malaysia, 2018). Furthermore, the Malaysian Security Commission is established with specific regulatory functions such as supervising exchanges, clearing houses, registering authorities, and approving and regulating issued bonds and Sukuk. The commission is also charged with the oversight functions of controlling all securities, future contracts, mergers and take-overs between companies. The commission is marketoriented as its provisions, guidelines and regulations evenly protect stakeholder issuers, investors and the market at large (Securities Commission Malaysia, 2018). As a consequence of an effort by the Malaysia SEC in discharging its regulatory functions, the Commission has produced some guidelines for the industry and stakeholders, particularly the Islamic finance industry. Among the guidelines drawn up by the commission are as follows:

Firstly, the Guidelines on the Issuance of Private Debt Securities and Sukuk to Retail Investors (SCGL/5-2015): The Malaysian Securities Commission produced these guidelines as a regulation and supervision framework for issuing private debt and Sukuk to retail investors. An essential part of the guidelines is about the corporate requirements for issuing private debt or Sukuk. Among these requirements are (Securities Commission Malaysia, 2013):

a. The guideline of eligibility requirements for the issuing firm stipulates that only listed public companies, licensed banks and Cagamas Bhd are allowed to issue PDS and Sukuk.

b. The guideline for rating requirements regulates that accredited Sukuk rating agencies must rate all private securities debt and Sukuk under the Security Commission.

c. Trustee and trust deed requirements stipulate that the issuer must co-opt with the trustee in ensuring the appropriate procedures of issuing local private debt securities Sukuk.

d. Implementation time frame: This guideline specifies that any PDS approved by the Securities Commission must be executed within the time frame of one year while any Sukuk approved by the Securities must be executed within two years.

e. Utilization of Proceeds: The guideline stipulates that PDS and Sukuk issued and approved by the Securities Commission must be utilized following the disclosed purposes in the prospectus and offering documents. Also, the Sukuk issued and approved must be utilized under the Sharī'ah compliancy rules.

Secondly, the Islamic Securities Guidelines (Sukuk Guidelines) Revised: 12 July 2011 Effective: 12 August 2011: The Capital market and Services Act 2007 CMSA with a subsection on Islamic securities and Sukuk has been provided to replace the guideline on the offering of Islamic securities of 2004. However, the CMSA 2007 stipulates that any person or corporate body willing to facilitate fundraising through Sukuk instruments must acquire the official approval of the Securities Commission of Malaysia (Securities Commission Malaysia, 2011).

\subsection{Laws on Default Issues:}

The Malaysian Act 1040, a securities amendment act no. 2 (1988), is one of the laws which empowers the Securities Commission with an oversight function to 
regulate and supervise the capital market industry and the Sukuk investment in Malaysia. The Act A1040 of the securities industry covers governing laws that bind stakeholders in capital market investment in Malaysia (Law of Malaysia, 1988).

Similarly, the act provides regulations for cross border investors who are willing to invest in the Malaysian market but are residing in different jurisdictions (Law of Malaysia, 1988). However, the act entails provisions that govern the bankruptcy procedure and the liquidation of individual and corporate bodies. The law dictates in general terms the actions of individuals or corporate entities that might trigger penalties or punishments in the processes of bankruptcy proceedings and the liquidation of properties (Securities Commission Malaysia, 2011).

On the other hand, the UAE regulations and supervision on Sukuk investment is partially based on common law and some elements of Sharī'ah law. The UAE officially published new standards for regulating and supervising Sukuk investments in Dubai. This effort is a laudable attempt mainly because of the challenges faced by the Islamic finance market in the UAE. These standards encapsulate regulation and clarity for problems arising from issuing, acquiring and trading Sukuk. This improvement aims to address, among others, the issue of Sukuk default that usually threatens the rights and interests of the investor (Sukuk holders) (Country Report, UAE, 2017).

The Dubai Financial Market standard no. 2, on the protection of the Sukuk investors' rights, stipulates that the Sukuk holders of every issuance can form an association with the common interest of protecting the rights of its members in the Sukuk investment. The association will continue to have legal representation throughout the contractual period of the Sukuk investment, after which it is dismissed by the Dubai Financial Market prospectus no. 13. The association is legally recognized so that it can protect its members' interest in the Sukuk investment by taking appropriate legal actions such as liquidation through filing for bankruptcy proceedings. The association, through membership resolution and legal consultation, will decide on the proper legal action against Sukuk default such as litigation or reconciliation through debt restructuring with the SPV or the originator of the
Sukuk investment (Dubai Financial Market Standards, n.d.).

The standard further stipulates that the originator or issuer is responsible for ensuring valid, accurate and comprehensive documentation of the contractual agreement to protect the rights of the Sukuk holders. Full disclosure about the nature of the contract, the project to be financed, and expected returns on the principal invested should be explicitly included in the originator's prospectus. (Dubai Financial Market Standards, n.d.).

Similarly, unfamiliar legal terms and clauses in the contract should be clearly written and explained to aid good decision making by the Sukuk holders. However, the standard states categorically that the originator shall bear the consequences of any attempt to conceal information or provide misleading data from misrepresentation which leads to liability. Another key point to mention is that the standard is binding on the contractual parties, but in case of issues or clauses not included in the rule, the AAOIFI Shar'̄'ah and accounting standards shall be the point of reference for the Sukuk contract (Dubai Financial Market Standards, n.d.)

\section{External Regulatory Elements}

Two basic international financial institutions that influence the regulatory actions of Malaysia and the UAE are the United Nations Commission on International Trade Law (UNCITRAL) and the Islamic Financial Service Board (IFSB). Although membership of these institutions are voluntary, they encourage every member to adopt and further its local framework following the international standard practices. The nature and extent of affiliation with these institutions have influenced one way or the other on the regulation of the capital market and on Sukuk especially.

\subsection{The United Nations Commission on International Trade Law (UNCITRAL):}

The United Nations Commission on International Trade Law (UNCITRAL) is the legal body of the United Nations system that provides for international trade law and the harmonization of businesses between member countries. The 
UNCITRAL was established forty years ago to formulate the conventional model law that can be acceptable by member states, provide a legal and legislative guide, update cases of law and provide technical assistance to member states to formulate their respective domestic commercial law in conformity with international standard practices (UNCITRAL, 2010). The UNCITRAL affiliation and member states cause significant differences between jurisdictions. Considering the UNCITRAL member states' history, the report shows that Malaysia had a membership registration between 2007-2019 while the United Arab Emirates had membership from 1968-1977 only. Until 2019, Malaysia remains a member of the UNICITRAL, while the United Arab Emirate is not. The implication is that the UNICITRAL law influence the UNCITRAL member states in the formation of the local regulations in conformity with international standards. Although the membership is voluntary, and it is set with specific criteria, yet this difference has shown a wide gap between the GCC countries and commonwealth nations like Malaysia (UNCITRAL, 2010).

However, after deliberations by the general assembly on the need to enhance harmonization and the unification of the international trade law among contractual parties from member states, the United Nations resolution 2205 (XXI) of 1966 was established to protect the interests of people in contractual agreements particularly those from developing countries. The United Nations effort in formulating the UNCITRAL arbitration rules is for settling the international commercial disputes that arise between the private commercial parties, investor versus state disputes, and state versus state disputes. This effort further assists member states to tailor their respective domestic commercial law in concord with the UNCITRAL model law (UNCITRAL, 2010). The UNCITRAL law relates more to the Jurisdiction of Malaysia compared to the UAE, which has discontinued membership since 1977. This is despite the view of some researchers that since the Islamic finance space needs its cross-border laws, industry engagement with the existing structure of UNCITRAL is better and more practical among member states. Each member nation is expected to formulate its regulations based on the cross border offer in UNCITRAL law (UNCITRAL, 2010).

\subsection{The Islamic Financial Service Board (IFSB):}

The Islamic Financial Service Board (IFSB) is one of the efforts by Malaysia, GCC and other member state regulatory institutions in providing regulations and supervision for the Islamic finance industry (IFSB, 2018). The Dubai Financial Service Authority and Bank Negara are full members of IFSB. In IFSB membership records, the Bank Negara Malaysia and the Central Bank of UAE have full membership status with various financial institutions within the jurisdiction as associate members or observers. This shows that the IFSB standards are recognized and applicable in Malaysia and the UAE (IFSB, 2018). The IFSB-standard no.19 is one of the standards which provides the Guiding Principles on Disclosure Requirements for the Islamic Capital Market Products (Sukuk and the Islamic Collective Investment Scheme). The IFSB regulations are in the form of standards which are established requirements in Sukuk investments and the Islamic Collective Investment Scheme. IFSB-19 is a formal document that establishes uniform criteria, methods, principles and practices for the Islamic capital market, specifically Sukuk. This standard is jointly developed by groups of member states, the international Sharī'ah scholars and the Islamic financial institutions (Islamic Financial Service Board, 2017).

However, the IFSB-19 standard covers disclosures on Sukuk from the initial stage of the offering of the Sukuk, as indicated in the prospectus, which can be either a periodic or an immediate situation. It is worth mentioning that the IFSB standard recognizes and benchmarks on the European economic regime as an exemplary best practice in the capital market. Hence IFSB is not meant to supersede the IOSCO ; instead it mainly attempts to complement the effort on specific issues about the Sukuk investment that must have been uncovered in IOSCO (International 
Organization of Securities Commission, 2019). Therefore, in the case of the contradiction between IOSCO and ICM (Islamic Capital Market), the IFSB standard prevails for the Sukuk investment alone. This standard is meant to protect the market mechanism and maintain a balance between investors and issuers. This is to ensure the adequacy of information to guide investor decisions, especially in Shari' ${ }^{\prime}$ ah related issues, while ensuring that issuers are not unnecessarily burdened in meeting the requirements (Islamic Financial Service Board, 2017).

The IFSB-19 standard focuses on general principles that apply to disclosure requirements for Sukuk and the Islamic Capital Investment Scheme (ICIS), specific disclosure principles for Sukuk, and principles for ICIS disclosures. These standards are the essential scope of this research (Islamic Financial Service Board, 2017).

One of the principles of the standard is "Principle G.1: Clear and Accurate Information: Information provided in offering documents or other documents prepared for investors and prospective investors should be clear, accurate and not misleading" (Islamic Financial Service Board, 2017).

Even though the stated standard is clear enough to help the market avoid issues that might trigger risks arising from defaults in Sukuk , the principle G.1 of the standard does not stipulate specific disclosure standards to be enforced by the regulatory and supervisory authorities (RSA); instead it recommends the IOSCO framework. Some experts further suggest that a disclosure framework should be adopted to aid in uniformity among the RSA. In the case where the obligor is not the same as the originator, the investors should be informed about the issuer's prospectus to understand beforehand the party that is to be bound to the contract and its financial obligation (Islamic Financial Service Board, 2017).

Furthermore, another principle is "Principle G.2: Sufficient Information: There should be full disclosure of information which a reasonable investor would view as useful to his/her decision on whether to invest or not" (Islamic Financial Service Board, 2017). This principle sets a specific framework on the disclosure of information by the issuers to guide the investors in their decision-making process. However, the issue of the disclosure of information by the issuer in sovereign and quasi-sovereign parties remains debatable among practitioners. The standard and good practice are that some capital market offerings should be exempted from a detailed disclosure, due to the nature of the offering (Islamic Financial Service Board, 2017). These may include securities by governments or multilateral financial institutions such as the Islamic Development Bank Group (IDBG) or the World Bank Group, and central banks, among others. Some practitioners and bank lobbyists argue that this is one of the issues that might trigger Sukuk default, particularly in cross-border situations (IDB Group, 2016).

Moreover, in the application of the Sukuk Disclosure to Cross-border Offering, the IFSB-19 standard on the cross-border offering of Sukuk states that in a situation where the issuers and offerees are in different jurisdictions, the international currency or the currency of the target market is taken into consideration. However, the standard recognizes the fact that most regulatory and supervisory authorities (RSAs) may not apply the same disclosure requirements to an offering because of cross-border jurisdiction and differences which make the application of disclosure requirements in cross-border offerings different from one to another (Islamic Financial Service Board, 2017).

The IFSB standards further indicate that one of the intents of the standards is to harmonize the Islamic Capital Market by providing the same disclosure for domestic offerings as well as cross-border offerings. Consequently, the board recommends that RSAs should not apply unnecessary burdens on private crossborder offerings (Islamic Financial Service Board, 2017).

The Principle S.1: of the general disclosure principles applicable to Sukuk also explicates the disclosure framework for any Sukuk that should reflect the characteristics of the securities. This standard is based on the Islamic legal maxim that states that "Intentions determine matters". This maxim is derived from the hadith of the Prophet (PBUH) "Actions are only [accurately assessed in the light of] intention and every person will earn what he/she intended" (Muslim, hadith no. 1907, 2006). The framework and 
characteristics of the structured product should be clearly reflected in the contractual agreement. That is, the intention of using the Islamic financial contract is to ensure Sharī'ah compliance of the contractual agreement (Marjan Muhammad et al., 2015).

The IFSB standards also include the harmonization of the standards for domestic and crossborder offerings. The IOSCO adopts a harmonized standard on disclosure for debt securities in crossborder offerings and as a basis for the domestic disclosure regimes. IOSCO contributes immensely to the harmonization of the capital market standards across jurisdictions in the conventional security market. (William Hicks J., 2002). However, the IFSB does not adopt the harmonization standards in its Islamic Capital Market. Islamic finance is yet to harmonize the disclosure requirements between the domestic Sukuk investment and cross-border offerings (IFSB, 2017). However, this study aims to further probe into the reasons why the IFSB is still lagging, what should be done and who is responsible for this harmonization in the IFSB standard, like IOSCO.

Under the IFSB-19, the disclosure provision states that the contract should specify the role of Shari'‘ah law in the interpretation of the Sukuk contracts. This disclosure requirement is essential for the selection and analysis of the governing law in the event of default, enforcement, amendment or restructuring. The standards further provide that in jurisdictions where Sharī'ah law is not binding, the contract should disclose the mandatory national law that would be used to interpret the Sukuk contract (Islamic Financial Service Board, 2017).

Moreover, in the event of a Sukuk default arising from an obligor's inability to fulfil its financial obligations, the provision states that all investors (creditors) should be treated in accordance with their contractual and legal expectations, without any bias in the available default remedial options such as restructuring of the Sukuk, enforcement following default, and acceleration and insolvency options. However, Sharī'ah considerations on the adaptability of these options and the limitations of ownership of the Sukuk holders are two important factors that will chiefly influence which option is appropriate and applicable (Islamic Financial Service Board, 2017).

\section{Juristic Analysis of Two Court Judgements}

This study discusses the issues that could arise and might possibly trigger default situations, from the prospectus of two selected cases from Malaysia and the UAE. In the case of Maybank trustee Berhad (MTB) Versus CIMB Bank Berhad, the issue of Al-Bai Bithaman Ajil (BBA) Bonds is popularly claimed to be the first Sukuk that became a subject matter in a Malaysian court (CIMB and Anor, 2011). The BBA bonds were issued by Pesaka Astana (M) Sdn Bhd with the intent of funding certain government contracts. The lead arranger for the BBA bonds was KAF Discounts Bhd while Maybank was the trustee to the BBA bonds (Hiu Choon Yuen, 2018). In this case, Maybank was finally declared liable for not providing adequate security for the investments of certificate holders due to negligence. The judgement was delivered at the Malaysian Court of Appeal on $8^{\text {th }}$ November 2011. The factual issue of the case was that Maybank Berhad filed a suit against CIMB and Anor (2011) about the Sukuk BBA contract. The claimant (MTB) appealed against the defendant (issuers, lead arranger, and significant shareholders) regarding the indemnity to be shared among certificate holders. The lead arranger for the issue was KAF Discounts Bhd (lead arranger), and the bond trustee was Maybank trustee Bhd (Bond trustee). The argument before the judge was that the defendant had defaulted in fulfilling its financial obligation of paying the proceeds of expected returns to certificate holders. The claimant argued that this default was because of negligence and the breach of duties in managing the capital of the investment (Hiu Choon Yuen, 2013). The claims of the certificate holders in the realization of their invested capital and damages were considered by the learned judge, who ruled that there was negligence on the part of MTB in the discharge of its responsibility, which triggered a violation of the right of the bondholders (Apnizan Abdullah \& Hakimah Yacoob, 2012). There was evidence before the court that explicated how the lead arranger of the contract was liable to the bondholders for the negligence of duty and breach of contractual agreement in the providing of responsible security for the capital under the contract (Apnizan Abdullah \& Hakimah 
Yacoob, 2012). Consequently, due to the evidence before the court, the judge at the court also found the trustee liable to the certificate holders for violating statutory duty. The court further decided that CIMB, who is the constructive trustee to the contract, is liable to repay MTB, which is the express trustee. The trustee argued that despite its liability for the negligence of statutory duty, the responsibility should not be beyond the amount deposited. Yet, the judge ordered that onethird of the total indemnity be paid to the issuers and other entities (Apnizan Abdullah \& Hakimah Yacoob, 2012). The court held that the majority shareholder and issuers, and CIMB (lead arranger) should be liable in part based on the contractual obligation. Therefore, the issuer and majority shareholders should indemnify the lead arranger and trustee for one-third of its face value, while CIMB should indemnify two-thirds of the bond to the bond trustee (Hiu Choon Yuen, 2018). Apnizan A. \& Hakimah Y. (2012) further explained in their work that even though the case is about an Islamic bond (Sukuk), the evidence presented in the case shows complete negligence on the part of CIMB. The authors further concur with the opinion of the judge that "bond issuance is a complex and sophisticated financial transaction that needs more heads than their hats" (Hiu Choon Yuen, 2018).

The second case to be discussed is between Dana Gas PJSC versus Dana Gas Sukuk Limited. This section explains the juristic and evaluative analysis of issues based on the argument and claims of the contractual parties. In the Dana Gas default court cases, the bottom line of the argument is that Dana Gas PJSC claimed some aspects of the Muḍārabah Sukuk contract is not Sharī'ah compliant as it contradicts basic principles of Sharī'ah and thus the contractual agreement should be considered a bond contract (Arif Sharif, 2017). The Dana Gas Sukuk holders, on the other hand, posited that despite the claim of nonSharī'ah compliance of the Sukuk contract, the Sukuk holders should have recourse to the underlying asset; as a result, default was triggered by the Shari'‘ah compliance issue. ${ }^{(4)}$ Therefore, the researchers recommend that as the creation of a global Islamic insolvency law might be challenging for the industry, alternatively, the principal stakeholders in Islamic finance such as AAOIFI, IFSB and OIC Fiqh Academy can lobby to be represented in the United Nations' UNCITRAL to address global issues that affect Islamic finance such as cross-border investment. It is also important that the rating agencies take Sharī'ah compliance risks into consideration. This will help avert future occurrences of default arising from non Sharī'ah compliance risks in the Sukuk contract (UNCITRAL, 2013). Consequently, the general perceptions of the Islamic finance space seem to have disapproved of Dana Gas PJSC on a moral ground. The Dana Gas PJSC should have called the stakeholders for debt restructuring rather than claiming non Sharī'ah compliance of the Muḍārabah contract (Rabah Bashir, 2018). The recent Dana Gas Sukuk default cases have triggered further considerations for tighter clauses in the Islamic financial contract, and hence, Sharī'ah advisors should ensure contractual agreements, particularly Sukuk investments, are compliant to Sharī'ah before Sharī'ah validation.

The initial injunction sought by Dana Gas PJSC from the Sharjah court claimed that certain elements in the Sukuk Muḍārabah were not Sharī'ah compliant based on UAE law and thus payment could not be made. The non-Sharī'ah compliant argument of the purchase undertaking in Dana Gas Sukuk involved guaranteeing the certificate holders the return from their investment by removing the risk of a loss of capital. Hence, the non-Sharī'ah compliance of the purchase undertaking is inconsistent with the prohibition of riba as compensation for the use of money (Dana Gas PJSC V. Dana Gas Șukūk Ltd \& Others, 2017). The non-Sharī' ah compliance claim by Dana Gas PJSC seemed suspicious to the Sukuk holders, especially since it was initiated at the maturity period. Furthermore, can the claimant prove to have been unaware of the grand verdict made by Sheikh Taqi Usmani and backed by AAOIFI, that partnership based Sukuk is not Sharī'ah compliant because it guarantees returns to certificate holders, what is forbidden in Islamic law. However, the legal and Sharī'ah experts of Dana Gas should have acted earlier to justify the essence of its claim (Taqi Usmani, 2008). An evident Islamic legal maxim is that the difficult circumstance of a party is not an excuse to violate the rights of others. Difficulty should not violate the rights of others. There are several verses of the Qur'ān which indicate 
exemptions for actions ordinarily forbidden by Shari'ah, as, due to necessity, the mukallaf is permitted with certain restrictions.

Several verses of the Quran have indicated this exemption, such as: "But whoever is forced [by necessity], neither desiring [it] nor transgressing [its limit], there is no sin upon him" [Al-Baqarah: 173]. Ibn Kathīr explicated that exceptions are permitted for those in difficulties if the subject is not doing it for committing sin or enmity. Hence, Rukhșah (concession) is not allowed for someone who got into difficulties because of committing sin or enmity (Ibn Kathīr, 1997). Similarly, Al-Qurtubī commented on this verse, positing that, if a person is in difficulty between the options of taking the food of others and eating dead meat, it is permissible to eat the food of others, and this position is agreed upon among scholars.

However, differences of opinion remain on whether the subject will be responsible for the rights of others (Al-Qurtubī, 2006). "But whoever is forced by severe hunger with no inclination to sin - then indeed, Allah is Forgiving and Merciful" [Al-Māidah: 3]. In the event of a mistake, that is unintentional or due to necessity, that affects the other parties' rights, these excuses cannot vitiate the claim of the other parties. For example, the maxims that says "necessity does not permit anyone to violate the other party's wealth". In this maxim, necessity or mistake or difficulty is not an excuse to violate the rights of others. However, in the event of such an action, the violator should be liable and responsible for the action (Al-Būrunū Abī Alhārith, 1996). Imam Șhāfî' also mentioned the difference between needs (Al-Hājah) and necessity ( $A l$ Darūrah). "Wa laysa bi al-Hājah Muharam illa fi aḍDarūrāt" or need is not an excuse for forbidding acts except in necessity (Al-Būrunū Ab̄̄ Al-ḥārith, 1996). Considering these evidences, whatever situation Dana Gas PJSC found itself in, such as cash flow issues and other financial distress, it was not an excuse to violate the contractual rights of certificate holders.

Muhammad Sidiqi explains that "necessity cannot vitiate the rights of others" means there is a limitation to the Rukhșah (concession) given to a subject, that is, the fact that a person who is in difficulty and is permitted to violate the rights of others, according to the verse above, shows that the exception is only limited to expiating his sins and is not a guarantee of freedom from responsibility for the other parties' rights. For example, if a person commits a sin under duress, the Rukhṣah (concession) can expiate his sins but will still hold him responsible for the damages done to the other parties (Al-Būrunū Abī Al-hạaith, 1996). Hence, even if there are reasons why Dana Gas has defaulted, the exception rule for difficult situations, such as credit issues and cash flow problems cannot vitiate the rights of other certificate holders (Busari, et al., 2019).

The principles of interdiction in Islamic law and its application are based on one of the main Islamic legal maxims "every difficulty must be eliminated" and many scholars have explicated that it is applicable in removing hardship from contractual parties in business transactions. Every hardship is bound to be removed but not with another hardship. However, hardship is injustice and all forms of difficulties arising from contractual agreement must be eliminated. A person is not expected to inflict hardship on himself, because every creature is an Amānah (trust) from Allah. Similarly, a person should not inflict hardship on other people, as they are creatures and trusts from Allah. This is because avoiding injustice is preferred over obtaining benefits (Muḥammad 'Azām, 2005).

Moreover, the purchase undertaking in Dana Gas documentation stated categorically that the English law is applicable and binding on contractual parties. And the Islamic maxims supported this position stating "the conditions among Muslims are binding except that which make forbidden what is permissible or make permissible what is forbidden" (Al-Tirmidhī, hadīth no. 1352, 1998).

\section{Conclusion and Recommendations}

This study has discussed the descriptive nature of the Islamic capital market and the governing framework in Malaysia and the UAE. The study also explained the governing law in these jurisdictions and the nature of their regulations. A juristic analysis of a court judgement was also demonstrated and finally, a comparison between the court judgements was performed, bearing in mind other influencing factors such as jurisdiction, governing law, the type of Sukuk 
contract and the underpinning contractual documents. The study further discussed the juristic analysis of selected court cases, namely, Maybank Berhad versus CIMB and Anor (2011) in Malaysia, and Dana Gas PJSC versus Dana Gas Ltd. The cases were discussed with a focus on the underpinning contractual agreements, as stated in their prospectuses. It is worth mentioning that the juristic analysis and discussion in this study are a rational explanation based on the background and understanding of the researchers using available literature.

The study also found out that the occurrence of Sukuk default can, however, be eminent due to two issues. Firstly, default from a scheduled payment, which is a delay or default on an agreed profit expected to be paid to the Sukuk holders at a periodic time within the time of maturity. Secondly, violation of contractual clauses, which is the violation and altering of terms included in the Sukuk contract that are legally binding on both parties. For example, if an issuer alters the contractual requirement that states the sales of the underlying asset to the investor through the SPV or the issuer violates the contractual clause, that was agreed upon through the promise, to repurchase the underlying asset after maturity. Similarly, a recent example was the step taken by the Dana Gas company in the UAE because it defaulted. It attempted to alter the validity of the contract by filing for a legal declaration of the nonSharī'ah compliance of the agreement through a court of law.

However, the experience of the Dana Gas Sukuk default shows clearly that the default situation in Sukuk investment can be better tackled and put in its proper shape in various jurisdictions if there are robust and comprehensive regulations. Also, in the Bloomberg interview session with Mr Muhammed Rafe Haneef (2017), on the fate of the Dana Gas Sukuk default, he opined that the antecedents to the case show that Dana Gas had a liquidity crunch and that was why it made such a declaration at the time of maturity. Mr Rafe further stressed that the claim was only trying to exploit the weakness of regulation and supervision in the UAE law, and he is sure that the case will be thrown out of the court in favour of the Sukuk holders. Experts have suggested the need to replicate what is presently practiced in Malaysia through adopting a national centralized Sharī'ah board in the Islamic finance industry. According to a research survey conducted on the adequacy of regulation and supervision in Sukuk default by Busari S.A. (2017), 95\% of the respondents suggested it is time for the stakeholders to adopt a centralised Sharī'ah board for cross border investment issues in the Islamic finance industry. The present research finds that the UNCITRAL insolvency law is a global model law that regulates the United Nations' member states and efforts are required on the part of the Islamic finance stakeholders to either lobby for representation at the UNCITRAL formulation and regulatory council to influence issues for cross border Sukuk investment or to create its own global Islamic insolvency law. Also, the principal institutions in the Islamic finance industry such as AAOIFI, ISRA, and IFSB should collaborate with the OIC Sharī'ah Academy to further the codification of appropriate clauses that can be included in contractual agreements to forestall future violations of Sharī'ah compliance issues in Islamic financial contracts, especially in Sukuk investment. It is probable that the major institutions need to consider the possibility of an appropriate penalty on Sharī'ah scholars who validate Shari' 'ah contracts in such a way that it leads to future misinterpretations.

\section{References}

'Abdul 'Azīz Muhammad 'Azām. 2005. Al-Qawā'id AlFiqhiyyah, (Al-Qāhirah: Dār al-Hadīth, p. 126.

Ahmad Ibrahim \& Ahilemah Joned. 1995. The Malaysian Legal System, 2 $2^{\text {nd }}$ Ed., (Kuala Lumpur: Dewan Bahasa dan Pustaka, 1995, p. 17.

Al-Qurtubī, Abu Abdullahi Muhammad bin Ahmad bin Abì Bakri. 2006. Al-Jāmi‘u Li Aḥkām Al-Qurān, Taḥqīq: Abdullah Muhsin Aturuqi, Țaba'ah 1, Juz 3, AlBaqarah 2: 173, (Bairūt: Al-Risālah Publisher, pp. 35-37.

Al-Tirmidhī. 1998. Muhammad bin Isa Abu Isa, Sunani AtTirmidhī, Taḥīq: Bashār 'Iwād Ma'rūf, (Bairut: Dār Garbī Al-Islām, hadith no. 1352.

Arif Sharif, Why is everyone talking about Dana Gas's șukūk, Retrieved on 24 03/2018, from https://www.bloomberg.com/news/articles/2017-06$\underline{15 / \text { dana-Gas-s-move-to-void-sukuk-stuns-analysts- }}$ who-question-motive.

Country report - UAE: New standards for $S u k u \bar{k}$, Extracted on $11 \quad$ October 2017 from https://www.bsabh.com/country-report-uae-newstandards-for-sukuk/.

Dana Gas PJSC (Claimant) V. Dana Gas Sukūk Ltd and others (defendant), Case No: FL-2017-000004, Royal Courts of Justice Strand, London, WC2A 2LL, Date: 17/11/2017. Retrieved on 05 June 2018 from: 
file://C:/Users/HP/Desktop/Causes\%20of\%20defaul t\%20sukuk/Dana-Gas-judgment.pdf.

David G. Epstein. 2010. Bankruptcy Materials and Cases, Third Edition, School of Law, University of Richmond Publication, American Case Book Series, (2010), 1-9.

David J. Billington \& Mohamed Taha. 2018. Can the Sukuk Industry Survive the Dana Gas Dispute? Emerging Markets Restructuring Journal, Issue no. 5, Deal News / UAE.

Dubai Financial Market Standards on Sharīah Compliance, Standard no. 2, Issuing, Acquiring and Trading Sukūk, P.12. Retrieved on 11 October 2018 from: http://www.dfm.ae/docs/default-source/Sharia/dfmstandard-for-issuing-acquiring-and-trading-șukūk .pdf.

Emily M. Weitzenböck. 2012. English Law of Contract: Terms of contract, Norwegian Research Center for Computers \& Law, pp. 3-19.

Enacted by Parliament of Malaysia. 1988. Law of Malaysia Act A1040, Securities industry (Amendment), no. 2, Act 1988. Retrieved on 18 November 2017 from: file://C:/Users/HP/Desktop/SC\%20Malaysia/SC\%2 0Default\%20law\%20Malaysia.pdf.

Ibn Kathīr, bin Umar, Ismā'īl. 1997. Tafsīr-al-Qurān-al'Azīm, Taḥqiq: Sāmī bin Muḥammad Al-Salāmah, Dar Tībah, 1999-1420, Taba'ah. 2. Vol.1, AlBaqarah: 173, (Al-Riyad: Dār Ṭībah, 1997-1418), pp. 480-481.

IDB, IRTI \& IFSB., 2015. Islamic Financial Services Industry Development, Ten-Year Framework and Strategies, Policy Dialogue paper no. 1, p. 3.

IFSB, 2017. The Reinvigorating the Momentum of Islamic Finance, Solidifying Resilience and Sustaining Growth, Summit Proceedings, pp. 1-56.

International Organization of Securities Commission. 2017. Annual Report, Regulators Statement on coin Offering, Retrieved on 10 January 2019 from https://www.iosco.org/about/?subsection=about iosc o.

J. William Hicks. 2002. Harmonization of Disclosure Standards for Cross-border Share Offerings: Approaching an "International Passport" to Capital Markets? Indiana Journal of Global Legal Study, Vol. 9, Issue 2, Article 1, pp. 1-21.

Kim Gittleson. 2013. What happens in a US debt default, extracted on 11 October 2017 from http://www.bbc.com/news/business-24453400.

Kuwait Finance House. 2017. "Introduction" in Șukūk Suruhanjaya Sekuriti Malaysia, Șukūk: Islamic Capital Market Series, Edited by AbdulKader Thomas (Malaysia, Sweet \& Maxwell Asia \& Thomas Reuters, p. IX.

Malaysia Security Commission, Extracted on 17/11/2017, from:

http://www.sc.com.my/main.asp?pageid=219\&menu id $=188 \&$ newsid $=\&$ linkid $=\&$ type $=$

Marjan Muhammad et al, 2015. Islamic Capital markets: principles and practices, (Kuala Lumpur: ISRA, p. 86.

Mohamad Akram Laldin \& Hafas Furqani, 2013. Islamic Financial Service Act (IFSA) and the Shariah compliant requirement of islamic finance in Malaysia. the ISRA International Journal of Islamic Finance by Emerald Publishing Limited. 2018.

Mohamed Haneef Rafe. 2017. Dana's case is a dud, won't hurt market, Retrieved on 17 April 2018, from: https://themalaysianreserve.com/2017/07/06/top- sukuk-underwriter-says-danas-case-dud-wont-hurtmarket/.

Mohd Faizal Kamarudin et al., 2014. Defaulter profile in Malaysia Sukūk market, Science Direct, Social and Behavioral Sciences.

Muhammad Sidiqī, bin Ahmad bin Muhammad Al-Būrunū Abī Al-hārith Al-Gazwī, Al-Wajīz fī ịdāh Qawa‘id Al-fiqh Al-Kuliyyah, Tabat $4^{\text {th }}$, (Bairūt: Mu'asasah Al-Risālah, 1996-1416), p. 244.

Muhammed Khnifer, 2017. An Islamic Debt Capital Market Banker at Islamic Development Bank Group analysis on: The Dickensian Dana Gas Sukūk lawsuit. Retrieved on 05/07/2017 from: https://www.economist.com/news/finance-andeconomics/21724416-borrower-refuses-paychallenging-sharia-compliance-its-bond-infant

Muslim bin Ḥujāj. 2006. Saḥị̣u Muslim, (Bairut: Dar Ṭībah Hadith, Al-Imārah No. 1907.

Rabah Bashir. 2018. English High Court: purchase undertaking securing Sukuk is valid and enforceable under English law, Retrieved on 10/01/2019 from; https://www.lexology.com/library/detail.aspx?g=620 d006a-943f-42da-9330-058caa3f2ad6.

Rafisah Mat Radzi \& Nurul Aini Muhamed. 2012. An International Comparative Study on Shariah Governance Supervision of Șukūk Default, Journal of Islamic Economics, Banking and Finance, Vol. 8 No. 3, pp. 36-38.

Robert S. Angyal. 1993. The Enforceability of Agreements to Mediate, Dispute Resolution, ACLN - Issue \#34, Retrieved on 10/01/2019, http://classic.austlii.edu.au/au/journals/AUConstrLa wNlr/1994/4.pdf .

Rodney Gerard D Cruz \& Murni Zuyati Zulkifli Aziz. 2017. legislative and Regulatory Framework, The Islamic Finance and marketplace, https://thelawreviews.co.uk/edition/the-islamicfinance-and-markets-review-edition2/1150798/malaysia.

Rusni Hassan. 2018. Comparative Regulatory Framework among South East Asian Nations, presented at the $6^{\text {th }}$ Asean university international Conference on Islamic Finance, held on $14^{\text {th }}-15^{\text {th }}$ November, Manila, Philippines.

Securities Commission Malaysia, Guidelines on Issuance of Private Debt Securities and Sukūk to Retail Investors (SC-GL/-2015). Extracted on 18/11/2017 from: file://C:/Users/HP/Desktop/SC\%20Malaysia/guideli nes_retailsPDS sukuk_150615.pdf.

Sheikh Taqi Usmani. 2008. Sukūk and their Contemporary Applications, (Port Elizabeth, South Africa, Mujlisul 'Ulamā of South Africa, p. 2.

Siḥr Abdullah Al-Ḥilmī. 2014. Al-Ṣukūk Al-Islāmiyyah Wa Dawruha fĩ Al-Tanmiyah Al-Iqtis̄ādiyah, Vol. 15, issue 4, Al-Nahda, pp. 85-104.

Steven Gandel, Here's How Much Faster U.S. Companies Are Defaulting Than a Year Ago, extracted on 11/10/2017 from: http://fortune.com/2016/07/25/u-s-corporatedefaults-double-in-2016/.

Suruhanjaya Securities: Securities Commission Malaysia, Islamic Capital Market, Retrieved on $3 / 05 / 2018$, https://www.sc.com.my/general_section/Islamiccapital-market/.

United Nations Commission on International Trade Law. 2010. Arbitration Rules (as Revised in 2010), (Austria: Vienna International Centre), 1. 
http://www.uncitral.org/uncitral/about/origin_history .html. Retrieved on: 06/01/2019.

United States Bankruptcy Court Western District of Louisiana Lafayette Division, Case no. 08-51207, Retrievedon02/04/2018

from:file://C:/Users/HP/Desktop/East\%20Cameron $\% 20$ Court\%20case/ECP\%20Petition.pd.

Zamani Abdul Ghani. 2007. Malaysia's role as an international Islamic financial centre BIS Review, 129: 4. Bank Negara, Securities Commission and Labuan Offshore.

\section{Endnotes}

(1) Robust Regulation and Comprehensive framework of Malaysia which include: the Federal law governing Islamic finance cases, the Islamic Financial Service Act (IFSA) which supervises and stipulates penalties for non-compliance, and the centralized Sharī'ah Advisory Council as the Centralized Sharī'ah Board with the Bank Negara and Securities Commissions Malaysia.

(2) Rusni Hassan, Comparative Regulatory Framework among South East Asian Nations, presented at the $6^{\text {th }}$ Asean University International Conference on Islamic Finance, held on $14^{\text {th }}-15^{\text {th }}$ November, (2018), Manila, Philippines.

(3) It is worth mentioning that the Malaysia regulatory framework has accommodated gradual and steady developments. The retail banking and Takaful act of 1983 launched the Malaysian Islamic finance space into action. Despite the significant growth of the industry, the Islamic capital market section of the Securities Commission was introduced later, after 10 years. The Malaysian accounting standard was also crucial in the framework for consideration of tax-related issues in the Islamic finance space. The IFSA act of 1983 stipulates a punishment of a fine of RM 25 million or 8 years imprisonment for whoever violates the Shari' ah compliant terms in contractual agreement.

(4) Daud Bakar, Prof., and CEO of Amanie Advisor, opined that Sukuk default arising from the Sharì ah compliance of a contractual agreement should not be welcomed. Once a fatwa has been made by a recognized scholar, the following fatwa on the same subject cannot invalidate the former. Instead, they are independent. He further argues that the legal counsel behind the Dana gas claim should be given a penalty if needed. 